\title{
Site-Based Management: \\ An Historical Perspective
}

by Joy L. Hoke

\section{Choice Career \\ CHALLENGING OPPORTUNITY}

Do you seek a truly professional position which allows you to set your own goals, formulate your own job description, and make decisions based on what you feel is important, not what is mandated by some far away paper shuffler?

Are you motivated, energetic, enthusiastic and strong in interpersonal skills? If so, look no further than filling the position of media coordinator on your local SBM team.

\section{UNLIMITED POTENTIAL FOR THE RIGHT INDIVIDUAL REQUIRES ENERGY, ENTHUSIASM, AND INTERPERSONAL SKILLS.}

\author{
SATISFACTION GUARANTEED
}

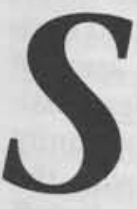

ite-Based Management, hereafter referred to as SBM, is a term used to describe the educational philosophy that local control of the school improves educational quality. It is essentially a process of decentralization in which decision-making authority is shifted to the school, yet authority over school policy is shared by the central office and the school site. This philosophy, currently being implemented in North Carolina school districts as a result of Senate Bill 2 legislation, creates avenues for the input of teachers, support staff, parents, and the community in the decision-making process. Paula A. White, writing in NASSP Bulletin, said that the ultimate goal of SBM is to improve the teaching and learning environment for students by decentralizing the decision-making process. ${ }^{1}$

White also says that budget, curriculum, and staffing decisions are three areas of decision-making most commonly decentralized under SBM. ${ }^{2}$ School site budgeting funds can be allocated according to priorities established at the school level. Materials and programs appropriate to the needs of the students can be correlated to curriculum developed by the school staff. Staffing decisions at the school level can enable the selection of individuals better suited to the school's goals and objectives and students' needs.

According to White, SBM promises greater flexibility and increased participation of school staff in school decisions. ${ }^{3}$ Cheryl R. Clark, a staff member of the Educational Research Service, states that teacher morale and motivation will be improvedby recognizing the merit of their professional opinions; likewise, greater accountability is predicted as school improvement plans designating clear lines of responsibility are implemented. ${ }^{4}$ The question remains, however, what benefit will SBM bring to school media coordinators and how can their participation insure a stronger SBM team?

Media coordinators must be an integral part of every SBM team if it is to be a successful vehicle for change. As certified teachers, they know curriculum; as media coordinators, they know materials which support curriculum. Without this powerful component of media services, the team is missing an important player. Change has been evident in media services as informa-

... the ultimate goal of Site-Based Management is to improve the teaching and learning environment for students by decentralizing the decision-making process.

tion has moved from print to high-tech retrieval, and media coordinators have successfully dealt with this area of change. Their role on the SBM team serves a double function: materials and curriculum specialist and change agent.

Media coordinators are key people in identifying programs and practices necessary to achieving school goals and thereby improving the teaching and learning environment for students. Performing their 
roles as information specialists, instructional consultants, and teachers, media coordinators are in the best position to link media resources and services to the needs of students and staff. Media coordinators bring to the SBM team information on innovative programs, practices, and new technologies which can assist in changing the school's goals and objectives.

Media coordinators provide expertise in the selection of resources, learning experiences, and instructional strategies for teaching and learning. As information specialists, media coordinators assist students and staff in accessing, selecting, and using resources and information. As instructional consultants, media coordinators assist teachers with instructional planning for student learning. As teachers, media coordinators are responsible for ensuring that information skills are an integral part of the school curriculum.

As members of SBM curriculum development teams, media coordinators will ensure the application of media to the learning process. Working with teachers and administrators in SBM planning teams, media coordinators can help define the information curriculum by transferring curriculum needs to media program goals and objectives. Working cooperatively with teachers to teach information skills, media coordinators can play a role in effective instruction.

Teachers are becoming more eager users of media services and more supportive of the role of media for several reasons. First, media coordinators recognize the need for an integrated program in presenting information skills. To secure this program, they are educating other teachers about the important role of media services. They are seizing opportunities to promote their product; they volunteer to serve on leadership and school improvement teams; they rely heavily on the input from Media Advisory Committees. Secondly, teachers are involved in resourcebased instruction, and have talked about resources and planned with the media coordinator to secure the best in materials to support the curriculum. This cooperative arrangement between classroom teachers and the media coordinator results in better instruction for the students - the only reason for schools to exist.

Media coordinators must emerge as leaders. "The leadership and commitment of the library media professional are crucial factors in developing credibility for the library media program as an integral part of teaching and learning in the school." ${ }^{5}$ Media

\section{Involvement in the Leadership Team}
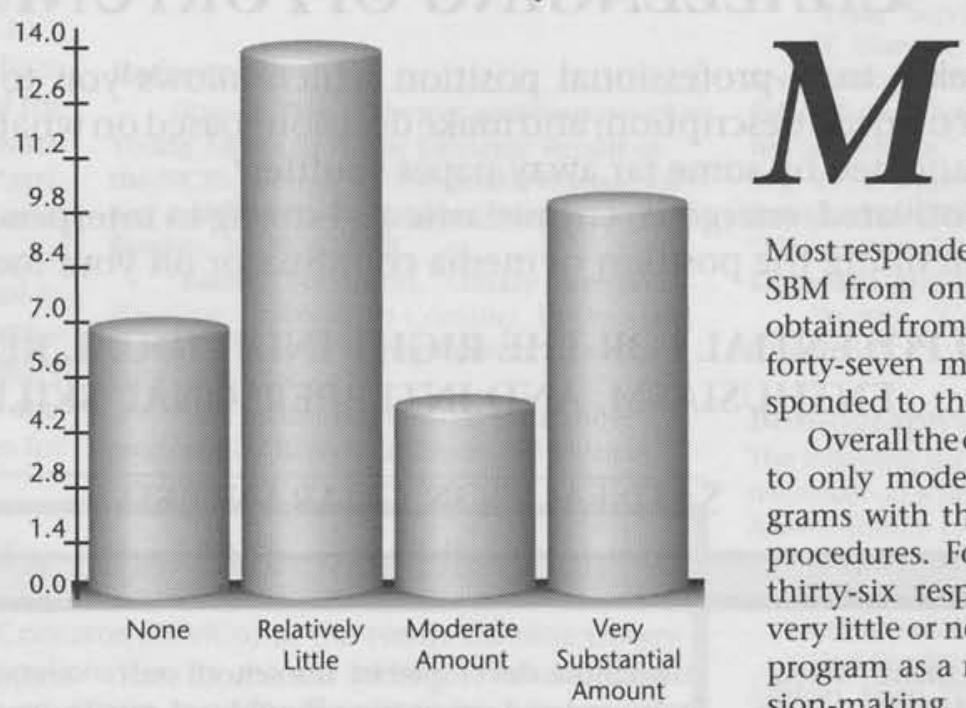

professionals have known that programs cannot be effective unless teachers and administrators understand and support the role a media program plays in the total school program. Information Power, the 1988 National Guidelines for School Library Media Programs, stresses the partnership role of the media coordinator. ${ }^{6}$ Media coordinators must establish administrative partnerships with principals and system-level media directors, as well as instructional partnerships with teachers, to ensure that media program goals become school goals. This role of partner is addressed in Media Program Recommendations, North Carolina's Guidelines for School Media Programs. ${ }^{7}$ Never has partnership been more important than now with SBM in effect.

A carefully planned public awareness campaign and continuing professional development in communication skills will enable media coordinators to create positive awareness of their media programs. Media coordinators who build good awareness on the part of administrators and teachers gain support for their programs.

\section{of SBM on media programs.} Most respondents had been involved with SBM from one to two years. Data was obtained from a sample of thirty-six out of forty-seven media coordinators who responded to the survey.

Overall the data indicates relatively little to only moderate change in media programs with the implementation of SBM procedures. For example, out of a total of thirty-six respondents, thirty reported very little or no change at all in the media program as a result of school-based decision-making. This was true in areas of budget, increased sense of professionalism, degree of flexibility and opportunity to make change, involvement with the school leadership team, and overall staff motivation. There was positive growth in

\section{Influence of the Leadership Team / Your Involvement in Media Decisions}

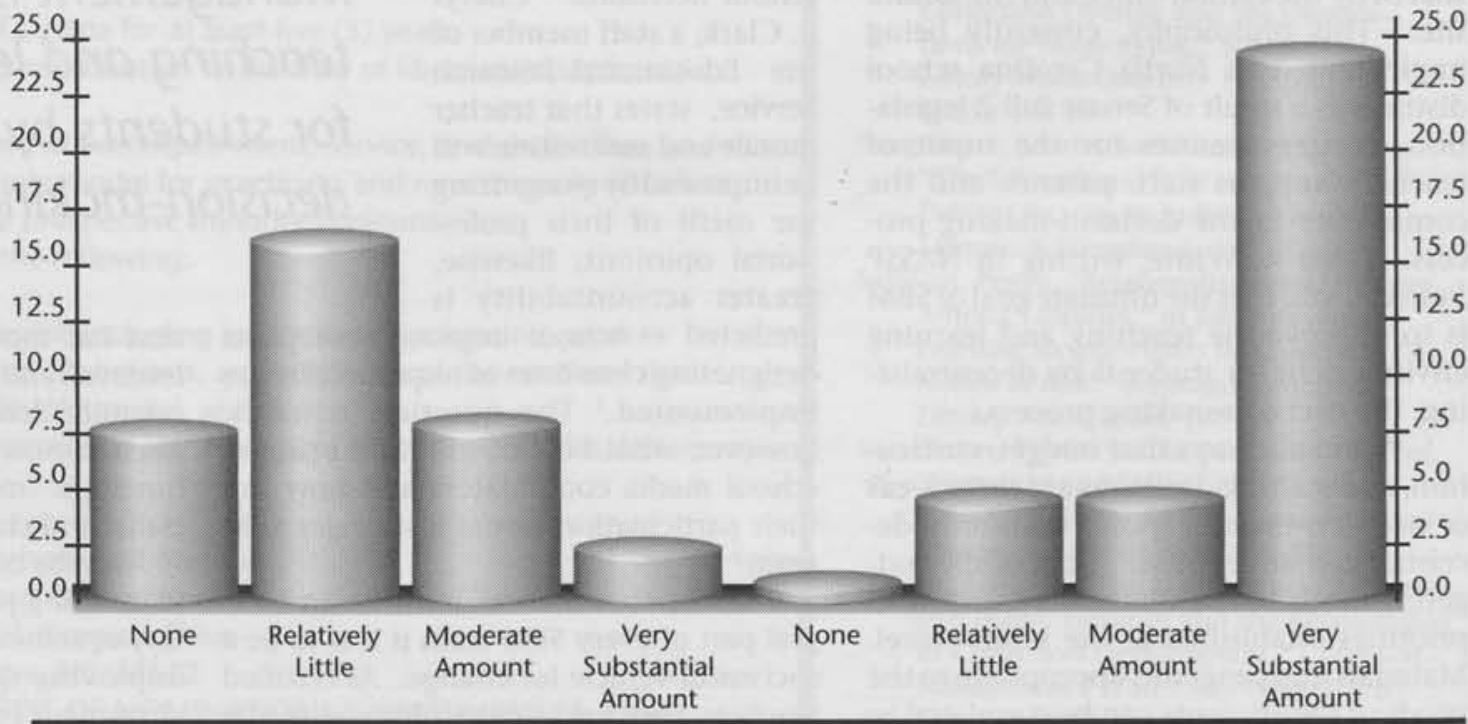




\section{Role Change of Media Advisory Committee}

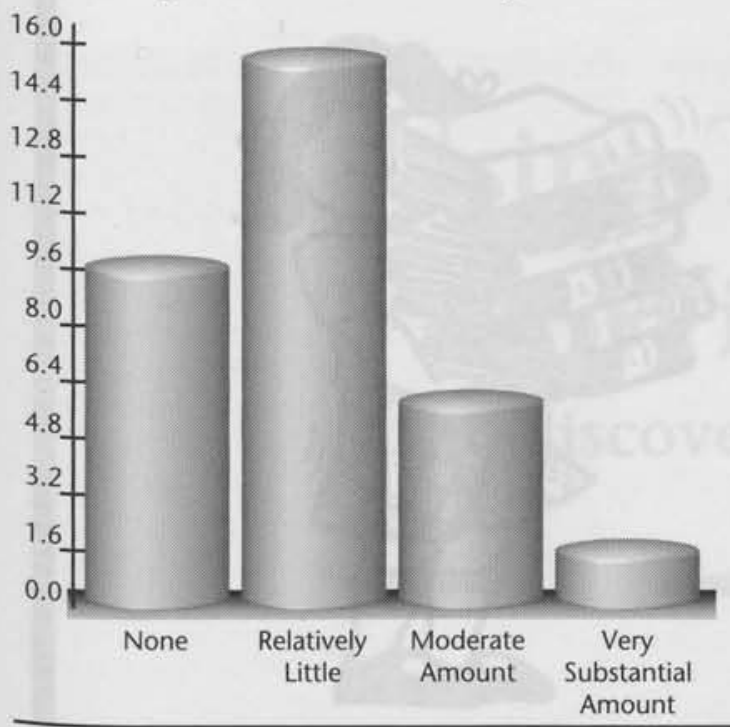

involvement with curriculum changes and in the shifting role of principals from decision-makers to facilitators.

Media coordinators were also given the opportunity to list advantages and disadvantages to SBM that had not been addressed in the survey. Among the advantages noted were the opportunities for greater input into the decision-making process, more latitude in expenditures, and an increased sense of respect for the role of the media coordinator from the respondents who are active members of their leadership teams.

Many of the disadvantages cited were related to the demands of time and energy placed upon team members. Also, several media coordinators reported jealousy and resentment by those not on the leadership team, personality conflicts among team members, and an over- zealous attempt by some members to obtain power.

Finally, although seldom involved with the leadership team in school-wide planning, most media coordinators report that they are fully involved with decisions that relate to the media program. These findings clearly indicate that the comprehensive role of media programs in the total school program is yet to be recognized. Media coordinators must accept the challenge and diligently attempt to convey the importance of the media component to the total school program. These efforts could be significantly enhanced if: 1) system-level improvement plans addressed media programs; 2) principals provided the motivation for a change that would integrate the media program into the instructional program; and 3) principals adjusted schedules to allow for planning time between media coordinators and teachers.

Empowerment of schools with decision-making authority can result in more effective media programs. A careful balance includes a supportive principal who is willing to unlock the door to initiate change, a committed media coordinator who provides leadership for change, and dedicated teachers in tune with the school's mission. This group, presentingstrategic instructional activities for change, offers unlimited opportunity for improved teaching and learning in the school.

Rather than empowering schools, SBM has the potential to enable schools to, as White states, " become more effective by providing more appropriate services to meet the specific needs of students." 8 Therein lies the potential for media programs - the potential for a fully integrated program serving school goals, providing access to information, and maximizing resources and energies for the entire school community.

\section{References}

'Paula A. White, "An Overview of School-Based Management: What Does the Research Say?," NAASP Bulletin 73, 518 (September 1989): 2.

Ibid., 2.

IIbid., 3.

${ }^{4}$ Cheryl R. Clark, Site-Based Management: An Information Folio (Arlington, Virginia: Educational Research Service, 1990), 1-2. ${ }^{5}$ American Association of School Librarians and Association for Educational Communications and Technology, Information Power (Chicago: American Library Association, 1988), 43. 'Ibid.

${ }^{7}$ Media Program Recommendations (Raleigh, North Carolina: Educational Media and Technology Services, State Department of Public Instruction, 1986), I-1.

${ }^{8}$ White, 3 .

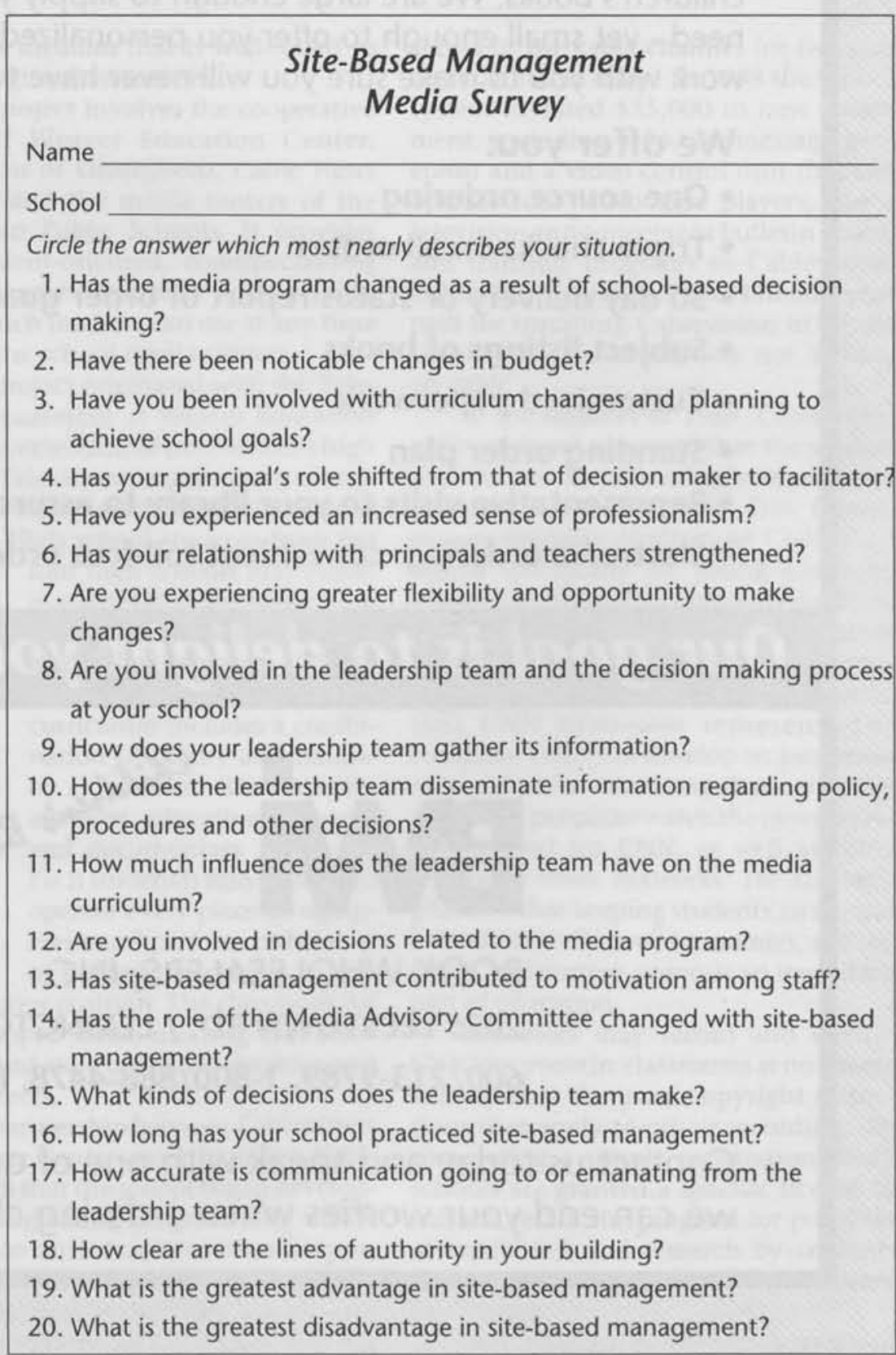




\section{Librarians, When your library needs children's books, why not consult with a specialist?}

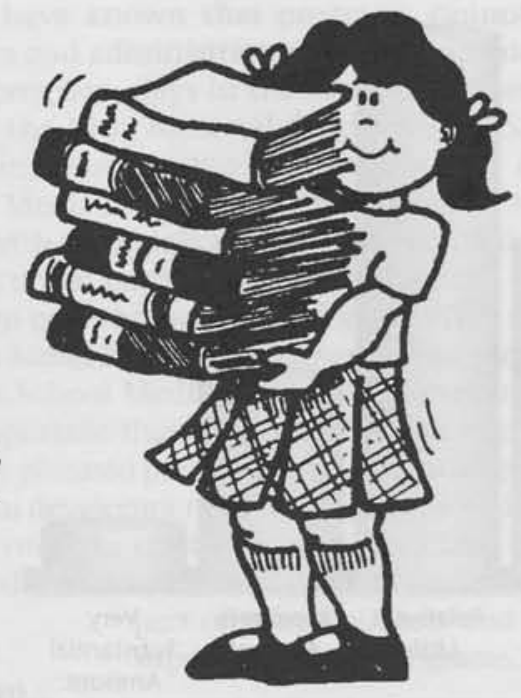

At Book Wholesalers, we specialize in supplying libraries with

children's books. We are large enough to supply you with every children's book you need - yet small enough to offer you personalized, dedicated service. Quite simply, we work with you to make sure you will never have to worry about children's books again.

We offer you:

- One source ordering

- Triple checks on all orders

- 30 day delivery or status report of order guaranteed

- Subject listings of books

- Customized paperwork

- Standing order plan

- Representative visits to your library to assure great service

- Electronic ordering: convenient toll-free ordering by FAX, telephone or computer

\section{Our goal is to delight you with our service.}

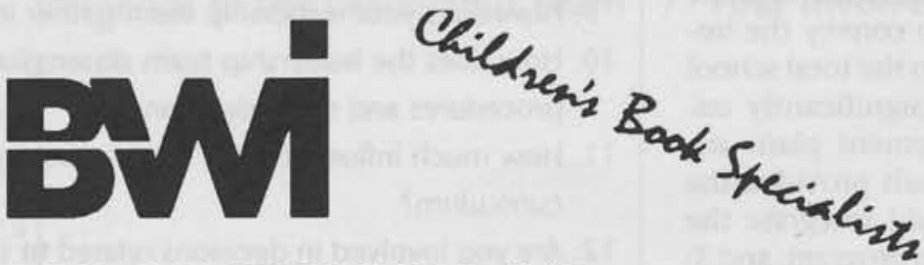

BOOK WHOLESALERS, INC.

2025 LEESTOWN RD. / LEXINGTON, KY. 40511

600/213-9789, 1-800/888-4478, FAX 1-800-888-6319

Contact us today and speak with one of our representatives about how we can end your worries when ordering children's books! 